Article

\title{
Delay Factors Management and Ranking for Reconstruction and Rehabilitation Projects Based on the Relative Importance Index (RII)
}

\author{
Basem Al Khatib, Yap Soon Poh and Ahmed El-Shafie *(D) \\ Department of Civil Engineering, Faculty of Engineering, University Malaya, Kuala Lumpur 50603, Malaysia; \\ eng.basemkhatib@gmail.com (B.A.K.); spyap@um.edu.my (Y.S.P.) \\ * Correspondence: elshafie@um.edu.my; Tel.: +60-379-677-651
}

Received: 8 July 2020; Accepted: 30 July 2020; Published: 31 July 2020

check for updates

\begin{abstract}
In recent decades, the construction industry has developed rapidly. Delay was and remains one of the most important challenges negatively affecting not only this industry but also the economy and sustainable development. This study aims to conduct a comprehensive analysis of the delay factors in reconstruction projects because of the vital importance of these types of projects. This is the first attempt to conduct such an analysis for reconstruction projects in particular, and it is a continuation of the previous case study, which was considered one of the most important reconstruction projects in the Middle East region. The previous study focused on determining the types of delay factors used in this project. It is necessary to carry out advance in-depth analysis to sort the delay factors based on their effect on the project plan. In order to achieve the study goal, 93 questionnaires were distributed by hand to experts working on the project: some of them working the day shift, and the others working the night shift. The questionnaire results were analyzed and delay factors were sorted in descending order according to the relative importance index (RII). The three main factors affecting the overall reconstruction project duration were site restrictions and conditions, electrical and mechanical rerouting works, and design buildability and adjustment.
\end{abstract}

Keywords: reconstruction projects; relative importance index; building rehabilitation; delay factors; ranking

\section{Introduction}

Delay is one of the most important challenges faced by the construction industry. Delay in a construction project is the variance between the actual project finish date and the contractual milestone finish date [1]. Another way to define delay in a project is as the variance between the real duration and the planned one [2]. Several significant studies have been carried out in various countries around the world to study the delay factors affecting construction projects. The main target of these studies was to lessen the negative impact of these delay factors on the project plans or completely prevent their effects. These impacts are not limited to the construction industry but also negatively affect the economy [3]. Studies that shed light on delay factors of reconstruction projects are still limited. For this reason, this study is concerned with this type of project, and is a continuation of a previous study conducted by the same researchers on the Mataf Expansion project in Mecca, Saudi Arabia. The delay factors have been identified in this project and classified into two groups in the previous study. The first is associated with the demolition and dismantling stage and includes the following: electrical and mechanical rerouting; the creation of safe passageways; site restrictions and conditions; historical element dismantling; and supporting works. The second group is related to the construction stage and includes the following: design buildability and adjustment; site restrictions and conditions; the creation of safe passageways; overlap between temporary projects and construction 
works; historical elements test period; alternative materials for historical elements; overlap between the historical and non-historical parts; workforce productivity rate; and delays in the building works next to the demolition area [4].

The main target of this study is to carry out a further evaluation of the delay factors associated with the reconstruction projects. An additional analysis is performed, including a more in-depth assessment of the ranking of the delay factors, utilizing questionnaire processing. Finally, this study will focus on accomplishing a wide-range analysis of the ranking of the delay factors for the reconstruction projects, according to their effects on the project planned duration, utilizing the relative importance index (RII) method.

Referring to previous studies, there is a set of delay factors that negatively affect construction projects and cause a delay. One of the most important delay factors mentioned repeatedly in previous studies is financial problems, whether of the contractor or the owner [5-8]. Another one is a shortage of skilled workers. A lack of workers who can complete the work with high accuracy and speed is often one reason for delay [9-12]. Another factor is improper planning, which results from inadequate study of the contractual project documents, site conditions, and available resources [13-22]. Among the delay factors mentioned in previous studies are the following: a change in orders [22-27]; delay and shortages of materials [28-32]; poor site management and supervision [33-35]; poor communication and coordination between construction parties [36,37]; design changes [38,39], lack of qualified and experienced personnel [40,41]; poor labor productivity [42]; subcontractors' incompetency [42]; bid award for lowest price [34]; lack of contractor experience [43]; poor contract management [43]; slow decision-making from the owner [27]; unrealistic project duration [44]; difficulties in obtaining work permits [33]; poor contractor management [45]; price escalation [46]; design errors [46]; construction mistakes [16]; design delays [20]; poor qualification of consultants [25]; shortage of equipment [31,36]; the type of contract [47]; unforeseen ground conditions [19,27]; weather conditions [9]; and political insecurity and instability [35].

\section{Research Methodology}

The same researchers' previous study was based on the case study methodology, which was carried out on the Mataf Expansion project through interviews with experts working on a project. This project consists of two main parts, nonhistorical and historical, as shown in Figure 1. It was divided into three major phases due to its significance, sensitivity, and incomplete closure, as shown in Figure 2. The work in each phase was divided into two main types, demolition and construction. Two demolition mockups were built for this project in the workshop area, one for the nonhistorical part and the other for the historical part, as shown in Figures 3 and 4 . In addition, there were two construction mockups, one for the nonhistorical part and the other for the historical part, as shown in Figures 5 and 6 . The aim of these four mockups was to determine the best demolition and construction methods and equipment that could be used in the project before starting the actual work on the site. In this project, it was the deviation between the project plans and the actual progress on the site that caused the project delay. The previous study was successful in determining the delay factors in this reconstruction project type, which were classified into two sections. The first was associated with five factors affecting the demolition and dismantling work: electrical and mechanical rerouting; the creation of safe passageways; site restrictions and conditions; historical element dismantling; and supporting works. The second section was associated with nine construction delay factors: design buildability and adjustment; site restrictions and conditions; the creation of safe passageways; overlap between temporary projects and construction works; historical elements test period; alternative materials for the historical elements; overlap between the historical and nonhistorical parts; workforce productivity rate; and delays in the building works next to the demolition area. In this study, a questionnaire was prepared based on the project delay factors resulting from the previous one. In fact, the questionnaire was designed to collect experts' opinions on the importance of delay factors affecting demolition and construction work. Then, their opinions were gathered on how significantly these factors were 
affecting demolition and construction work. The goals were, first, to study the demolition delay factors' effect on the demolition's planned duration. Second, to study the construction delay factors' effect on the construction's planned duration. Third, to study the demolition and construction factors' combined effect on the overall planned reconstruction's duration. In order to achieve this target, the questionnaire was divided into three parts. The first part was related to factors affecting demolition duration. The second part was related to factors affecting construction duration. The third and final one was related to demolition and construction factors combined, and studied their impact on the overall planned reconstruction's duration. A four-point Likert scale was adopted in the questionnaire, where 1 = strongly disagree, $2=$ disagree, 3 = agree, $4=$ strongly agree, in order to rank the delay factors' significance and effects on project duration.

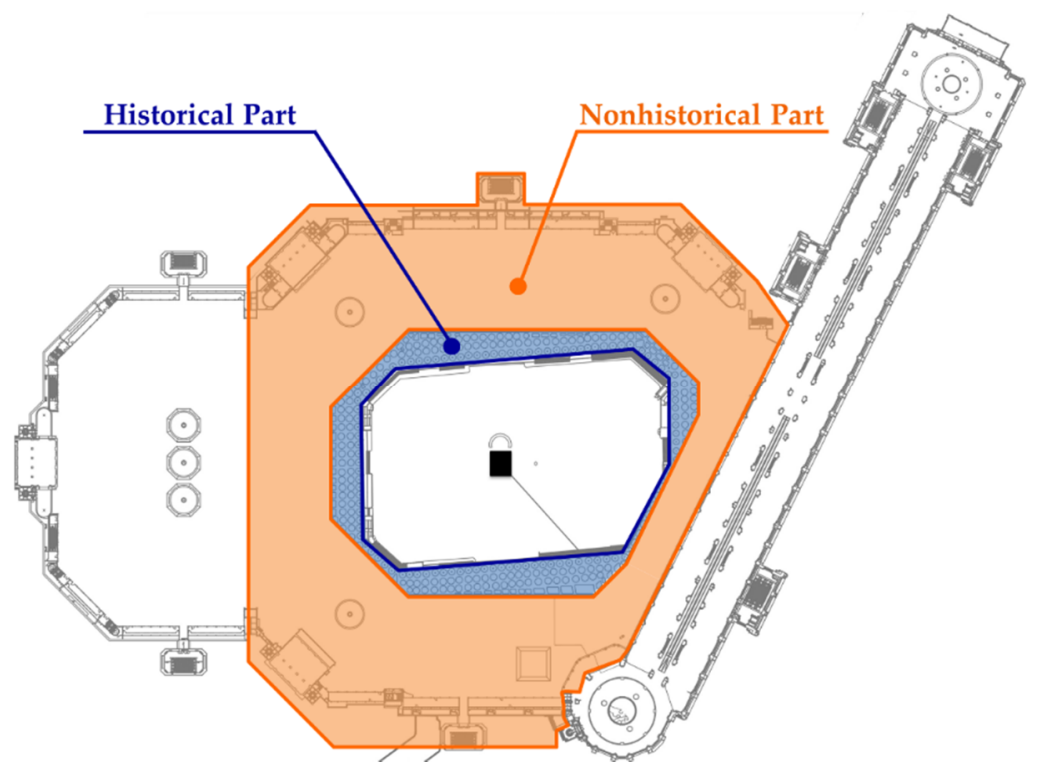

Figure 1. The Mataf Expansion Project's main parts with the historical part shown in blue and the nonhistorical part shown in orange.

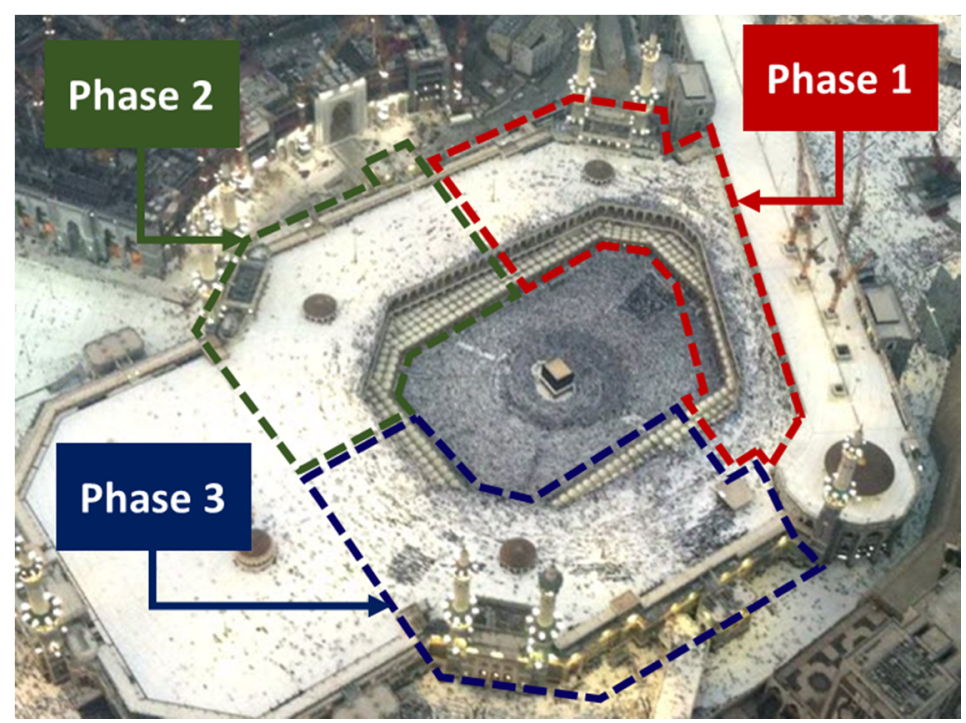

Figure 2. Mataf Expansion Project: the three main phases for reconstruction work. Phase 1 is outlined in red, phase 2 is outlined in green, and phase 3 is outlined in blue. 


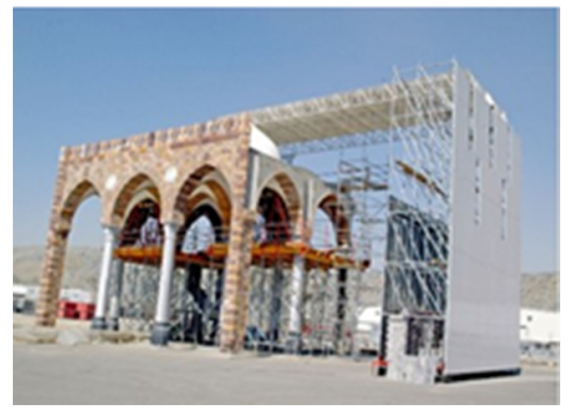

Figure 3. Demolition mockup for the historical part in the workshop area.

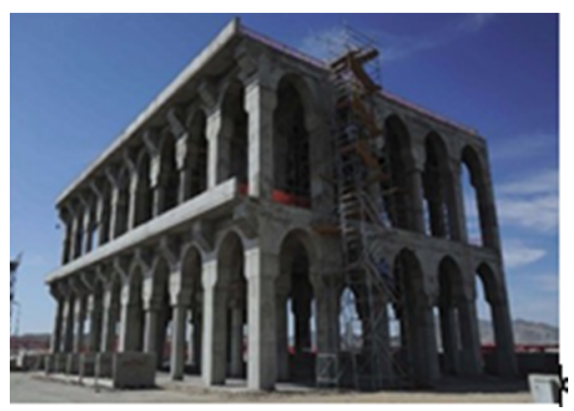

Figure 4. Demolition mockup for the nonhistorical part in the workshop area.

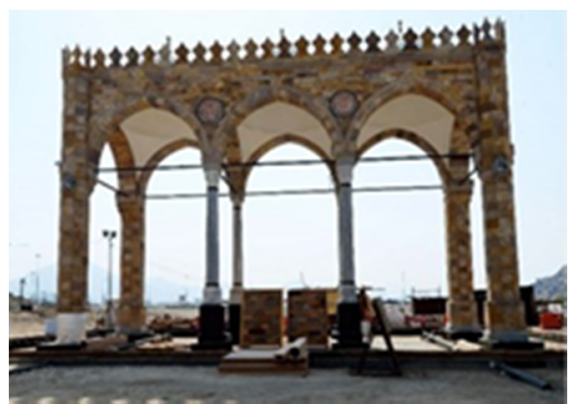

Figure 5. Construction mockup for the historical part in the workshop area.



Figure 6. Construction mockup for the nonhistorical part in the workshop area.

The site was visited many times, and appointments were set up with the experts working on the project in order to fill out the questionnaire after informing them about this study's goals. Some of these appointments were in the morning, while the others were in the evening. All the appointments were set up according to the experts' working conditions and free time to fill in the questionnaire as accurately as possible and in a way that reflects the reality of the project work. Before distributing the questionnaire to the experts, we discussed it with two construction managers to check that the delay factors were described clearly. In fact, these two interviews had an important role in the study as some 
points in the questionnaire were modified based on their recommendations. In addition, they advised us to distribute the questionnaire to experts who had worked for more than a year and could evaluate the delay factors' significance according to their experience in this project. It should be mentioned here that the experts who responded to the questionnaire were professional engineers with various specialties and different levels in the project organizational chart. Table 1 shows the 93 respondents to the questionnaire and their position in terms of their level, job title, number within the group, and the percentage to the total number of respondents. The first group was the managers, with different job titles, and the percentage of respondents at the manager level was $11.8 \%$. The second group was the senior level; the number of successful seniors was 22 (almost $23.7 \%$ of the total number of respondents), while the last group was the junior engineers with the highest number of respondents equal to 60 ( $64.5 \%$ of the total respondents). In fact, about $35 \%$ of the respondents were from both managerial and senior levels together. This large percentage positively reflects the high level of confidence in the achieved delay factors and their evaluation. This is because of the differences in the experts' experience, in addition to their awareness of the project, and the real details of the delay factors which were discussed in the weekly progress meetings.

The research methodology and study framework can be summarized as shown in Figure 7.

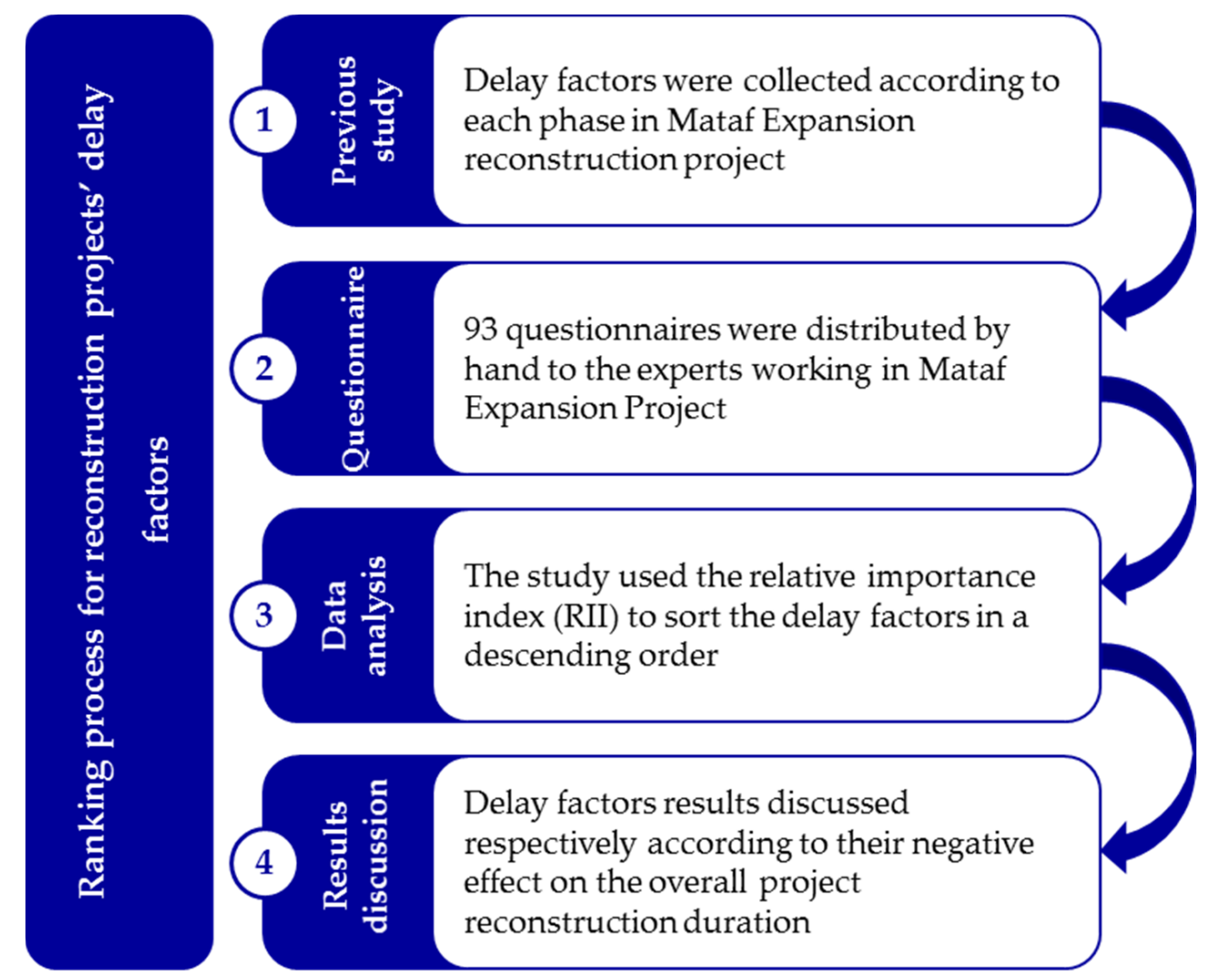

Figure 7. Research methodology and study framework. 
Table 1. Expert/Respondent's information.

\begin{tabular}{clcc}
\hline Expert/Respondent's Level & \multicolumn{1}{c}{ Job Title } & Total Number & Total Percentage \\
\hline \multirow{3}{*}{ Manager } & $\begin{array}{l}\text { Project manager, construction manager, } \\
\text { technical manager, project control } \\
\text { manager, logistics manager, planning } \\
\text { manager, quality manager, safety } \\
\text { manager, workshop manager }\end{array}$ & 11 & $11.8 \%$ \\
& $\begin{array}{l}\text { Senior planning engineer, senior quality } \\
\text { engineer, Senior site engineer } \\
\text { (structural, electrical, mechanical and } \\
\text { architectural), senior technical engineer } \\
\text { (structural, electrical, mechanical and } \\
\text { architectural), senior safety engineer }\end{array}$ & 22 & $23.7 \%$ \\
\hline Jenior & $\begin{array}{l}\text { Planning engineer, quality engineer, site } \\
\text { engineer (structural, electrical, } \\
\text { mechanical and architectural), technical } \\
\text { engineer (structural, electrical, } \\
\text { mechanical and architectural) }\end{array}$ & 60 & \\
\hline Overall respondents & & & $64.5 \%$ \\
\hline
\end{tabular}

\section{Data Analysis}

This study agrees with the view that using the mean in addition to the standard deviation of each single factor's attribute is not a suitable way to evaluate the overall rankings as they do not reflect any relationship between them. The suggested method for sorting the factors is using the relative importance index (RII) $[3,6,14,16,19,20,24,25,31,32,38]$. As a result, this study used the relative importance index (RII) to define the comparative ranking of the delay factors that can be calculated based on the following formula:

$$
\text { Relative Importance Index }(\mathrm{RII})=\frac{\sum w}{A * N}=\frac{1 n_{1}+2 n_{2}+3 n_{3}+4 n_{4}}{4 * N} ;(0 \leq \mathrm{RII} \leq 1)
$$

where the symbols indicate:

- W: weight was given to each delay factor by the respondent within the range $\{1,2,3,4\}$, multiplied by the number of respondents $\left\{n_{1}, n_{2}, n_{3}, n_{4}\right\}$ for each factor;

- $\quad n_{1}=$ number of respondents who strongly disagree;

- $n_{2}=$ number of respondents who disagree;

- $\quad n_{3}=$ number of respondents who agree;

- $n_{4}=$ number of respondents who strongly agree;

- A: highest weight (in this study: 4);

- $\quad N$ : overall number of respondents (in this study: 93).

According to the relative importance index (RII) results, the delay factors were sorted in descending order of rank. The highest RII value refers to the factor that causes the maximum delay, while the lowest RII value refers to the factor that causes the least delay. By using the previous formula, the questionnaire analysis results were organized into three tables. Table 2 presents the delay factors that negatively affected the demolition phase duration. Table 3 presents the delay factors that negatively affected the construction phase duration. Table 4 presents the delay factors that negatively affected the overall project reconstruction duration. 
Table 2. Delay factor analysis results for the demolition phase.

\begin{tabular}{llcccccc}
\hline \multirow{2}{*}{ No. } & \multicolumn{2}{c}{ Delay Factor } & \multicolumn{2}{c}{ Percentage of Respondents Scoring } & \multirow{2}{*}{ RII } & \multirow{2}{*}{ Rank } \\
\cline { 3 - 6 } & & $\begin{array}{c}\text { Strongly } \\
\text { Agree }\end{array}$ & Agree & Disagree & $\begin{array}{c}\text { Strongly } \\
\text { Disagree }\end{array}$ & & \\
\hline 1 & Electrical and mechanical rerouting works & $82.8 \%$ & $17.2 \%$ & $0.0 \%$ & $0.0 \%$ & 0.957 & 2 \\
\hline 2 & The creation of safe passageways & $66.7 \%$ & $33.3 \%$ & $0.0 \%$ & $0.0 \%$ & 0.917 & 3 \\
\hline 3 & Site restrictions and conditions & $84.9 \%$ & $15.1 \%$ & $0.0 \%$ & $0.0 \%$ & 0.962 & 1 \\
\hline 4 & Historical element dismantling & $58.1 \%$ & $34.4 \%$ & $7.5 \%$ & $0.0 \%$ & 0.876 & 4 \\
\hline 5 & Supporting works & $29.0 \%$ & $36.6 \%$ & $22.6 \%$ & $11.8 \%$ & 0.707 & 5 \\
\hline
\end{tabular}

Table 3. Delay factor analysis results for the construction phase.

\begin{tabular}{lllccccc}
\hline \multirow{2}{*}{ No. } & \multicolumn{1}{c}{ Delay Factor } & \multicolumn{2}{c}{ Percentage of Respondents Scoring } & \multirow{2}{*}{ RII } & \multirow{2}{*}{ Rank } \\
\cline { 3 - 6 } & & $\begin{array}{c}\text { Strongly } \\
\text { Agree }\end{array}$ & Agree & Disagree & $\begin{array}{c}\text { Strongly } \\
\text { Disagree }\end{array}$ & \\
\hline 1 & Design buildability and adjustment & $76.3 \%$ & $23.7 \%$ & $0.0 \%$ & $0.0 \%$ & 0.941 & 2 \\
\hline 2 & The creation of safe passageways & $53.8 \%$ & $31.2 \%$ & $12.9 \%$ & $2.2 \%$ & 0.841 & 6 \\
\hline 3 & Site restrictions and conditions & $81.7 \%$ & $18.3 \%$ & $0.0 \%$ & $0.0 \%$ & 0.954 & 1 \\
\hline 4 & Overlap between temporary projects and construction works & $65.6 \%$ & $21.5 \%$ & $8.6 \%$ & $4.3 \%$ & 0.871 & 4 \\
\hline 5 & Historical elements test period & $74.2 \%$ & $18.3 \%$ & $5.4 \%$ & $2.2 \%$ & 0.911 & 3 \\
\hline 6 & Alternative materials for the historical elements & $43.0 \%$ & $30.1 \%$ & $17.2 \%$ & $9.7 \%$ & 0.766 & 7 \\
\hline 7 & Overlap between the historical and nonhistorical parts & $40.9 \%$ & $30.1 \%$ & $18.3 \%$ & $10.8 \%$ & 0.753 & 8 \\
\hline 8 & Workforce productivity rate & $62.4 \%$ & $21.5 \%$ & $11.8 \%$ & $4.3 \%$ & 0.855 & 5 \\
\hline 9 & Delays in the building works next to the demolition area & $22.6 \%$ & $33.3 \%$ & $24.7 \%$ & $19.4 \%$ & 0.648 & 9 \\
\hline
\end{tabular}

Table 4. Delay factor analysis results for the overall reconstruction project.

\begin{tabular}{clcccccc}
\hline \multirow{2}{*}{ No. } & \multirow{2}{*}{ Delay Factor } & \multicolumn{2}{c}{ Percentage of Respondents Scoring } & \multirow{2}{*}{ RII } & \multirow{2}{*}{ Rank } \\
\cline { 3 - 6 } & & $\begin{array}{c}\text { Strongly } \\
\text { Agree }\end{array}$ & Agree & Disagree & $\begin{array}{c}\text { Strongly } \\
\text { Disagree }\end{array}$ & \\
\hline 1 & Electrical and mechanical rerouting works & $76.3 \%$ & $23.7 \%$ & $0.0 \%$ & $0.0 \%$ & 0.941 & 2 \\
\hline 2 & Historical element dismantling & $54.8 \%$ & $35.5 \%$ & $9.7 \%$ & $0.0 \%$ & 0.863 & 5 \\
\hline 3 & Supporting works & $28.0 \%$ & $36.6 \%$ & $22.6 \%$ & $12.9 \%$ & 0.699 & 11 \\
\hline 4 & Design buildability and adjustment & $74.2 \%$ & $25.8 \%$ & $0.0 \%$ & $0.0 \%$ & 0.935 & 3 \\
\hline 5 & The creation of safe passageways & $63.4 \%$ & $22.6 \%$ & $12.9 \%$ & $1.1 \%$ & 0.871 & 4 \\
\hline 6 & Site restrictions and conditions & $80.6 \%$ & $19.4 \%$ & $0.0 \%$ & $0.0 \%$ & 0.952 & 1 \\
\hline 7 & Overlap between temporary projects and construction works & $62.4 \%$ & $21.5 \%$ & $11.8 \%$ & $4.3 \%$ & 0.855 & 6 \\
\hline 8 & Historical elements test period & $54.8 \%$ & $32.3 \%$ & $9.7 \%$ & $3.2 \%$ & 0.847 & 7 \\
\hline 9 & Alternative materials for the historical elements & $37.6 \%$ & $32.3 \%$ & $20.4 \%$ & $9.7 \%$ & 0.745 & 10 \\
\hline 10 & Overlap between the historical and nonhistorical parts & $39.8 \%$ & $30.1 \%$ & $19.4 \%$ & $10.8 \%$ & 0.747 & 9 \\
\hline 11 & Workforce productivity rate & $54.8 \%$ & $28.0 \%$ & $12.9 \%$ & $4.3 \%$ & 0.833 & 8 \\
\hline 12 & Delays in the building works next to the demolition area & $21.5 \%$ & $32.3 \%$ & $26.9 \%$ & $19.4 \%$ & 0.640 & 12 \\
\hline & & & & & & & \\
\hline
\end{tabular}

\section{Discussion}

These results show that there is agreement of the importance of the site restrictions and conditions. This factor came first in terms of its impact on the overall project duration according to Table 4 , where RII $=0.952$ and Rank $=1$. It also came first with respect to the effect on the demolition phase duration according to Table $2(\mathrm{RII}=0.962$, Rank $=1$ ) and with respect to the impact on the construction phase duration according to Table $3(\mathrm{RII}=0.954$, Rank $=1)$. There was a big difference between the site conditions during demolition and construction mockups, which were built in special workshops, and site conditions during work on the project. This difference resulted from a set of points. Firstly, 
the mockups could be easily accessed and worked on from all sides, whereas the project site is not easily accessible, so work is restricted to specific aspects, as shown in Figures 8 and 9.

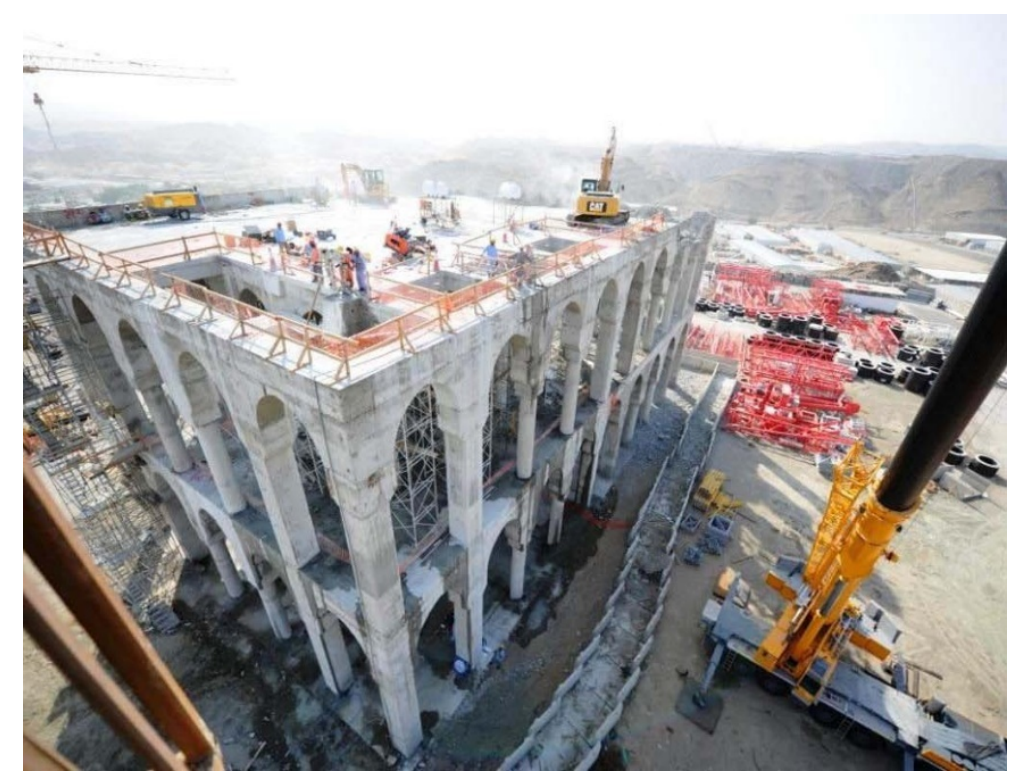

Figure 8. Demolition mockup for accessibility.

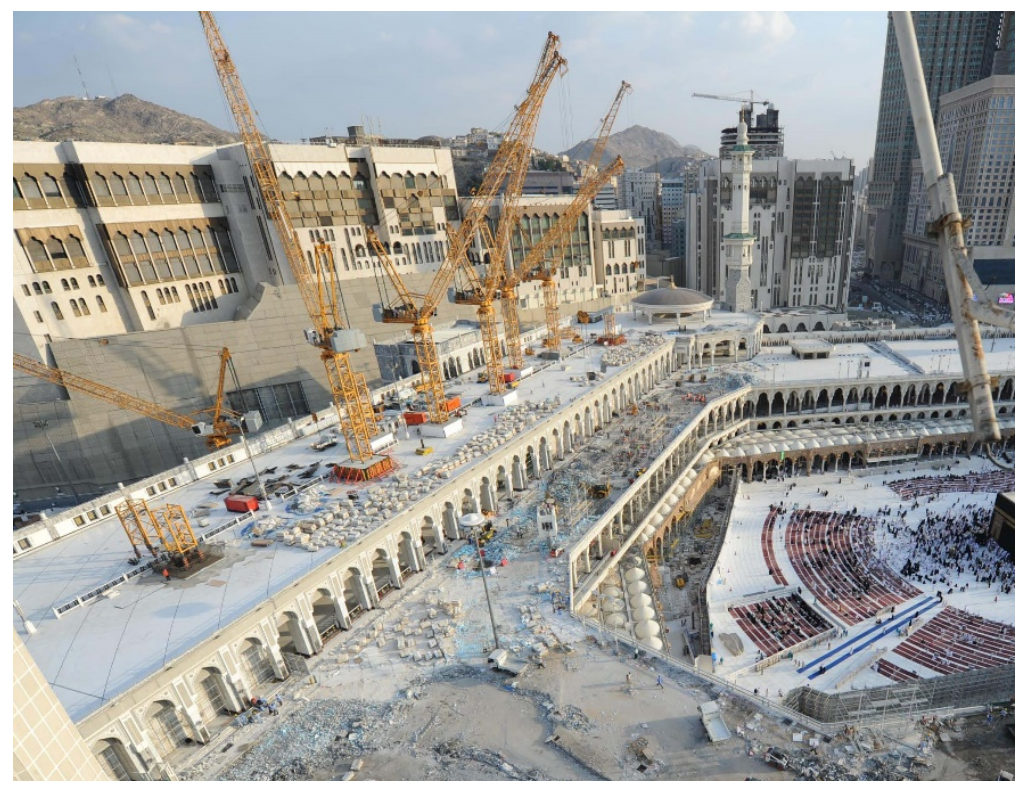

Figure 9. The project site itself, showing it is not easily accessible.

Second, there are no restrictions on the size of equipment used for demolition and construction within the workshop area where demolition and construction mockups were built due to the availability of wide tracks and entrances, but this is not the case on the actual project site, where there are restrictions on large equipment due to the narrow tracks. This means that equipment, demolition debris, and building materials are often transported using tower cranes, as shown in Figures 10 and 11. 


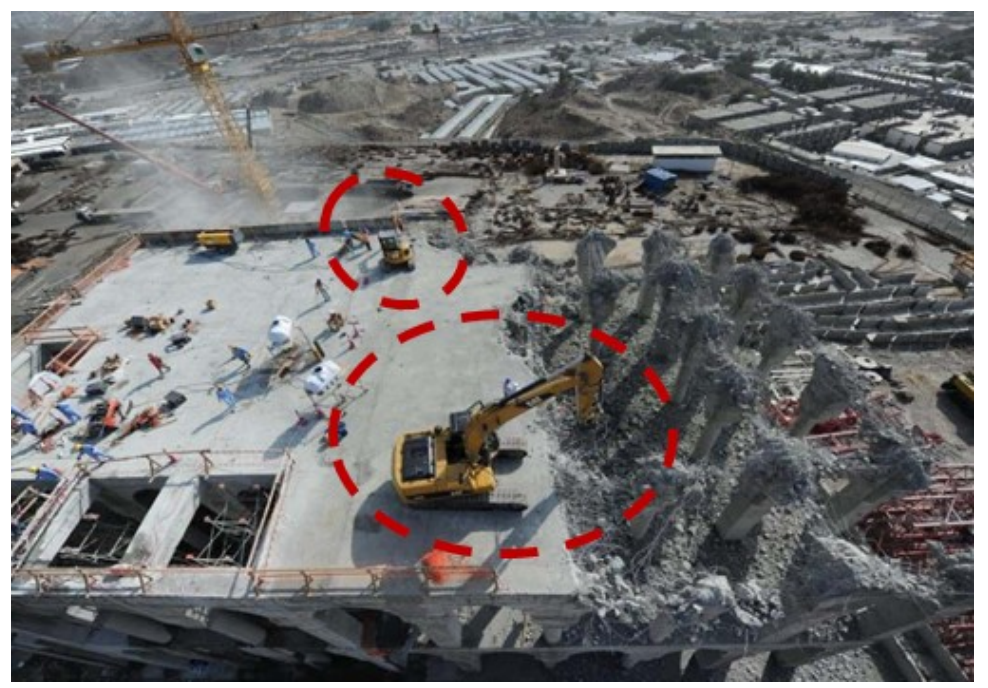

Figure 10. Large (in the bottom red circle) and small (in the top red circle) machinery at the demolition mockup.

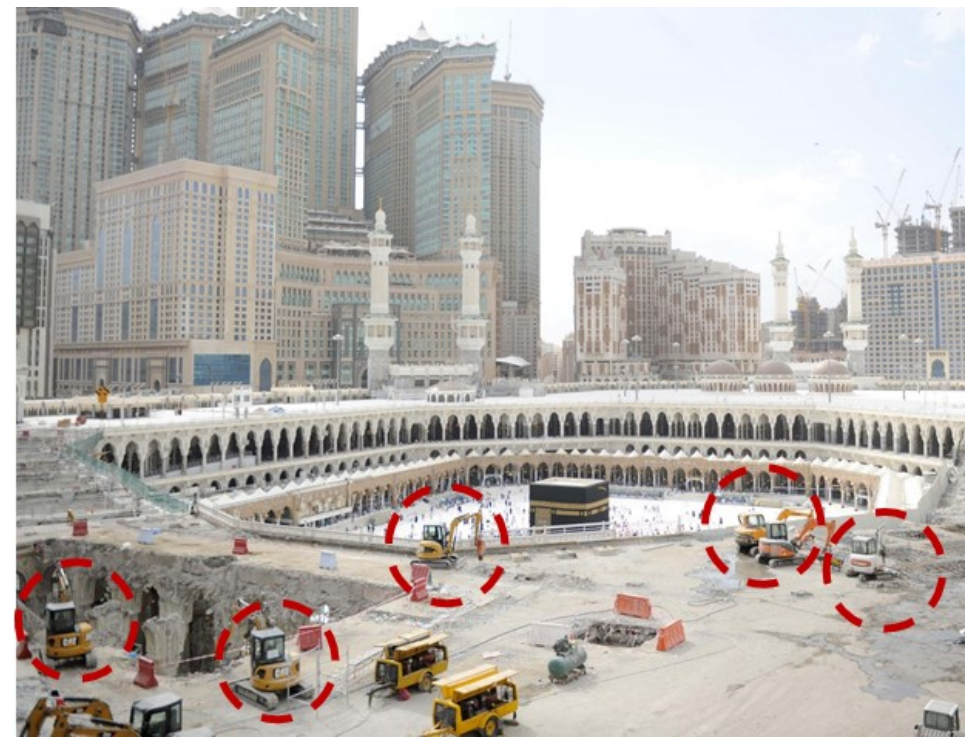

Figure 11. Small machinery (shown in the red circles) at the project site.

Third, the mockup area is completely closed off to visitors, which allows work to continue without interruptions or special safety requirements. Fourth, demolition work started immediately on the mockup without the need for any mobilization or preliminary work, unlike the project, where demolition work did not start until after historical documentation, dismantling and packaging holdings, and building fences that mimic the project shape-For safety and to maintain the general view-As shown in Figures 12 and 13. 


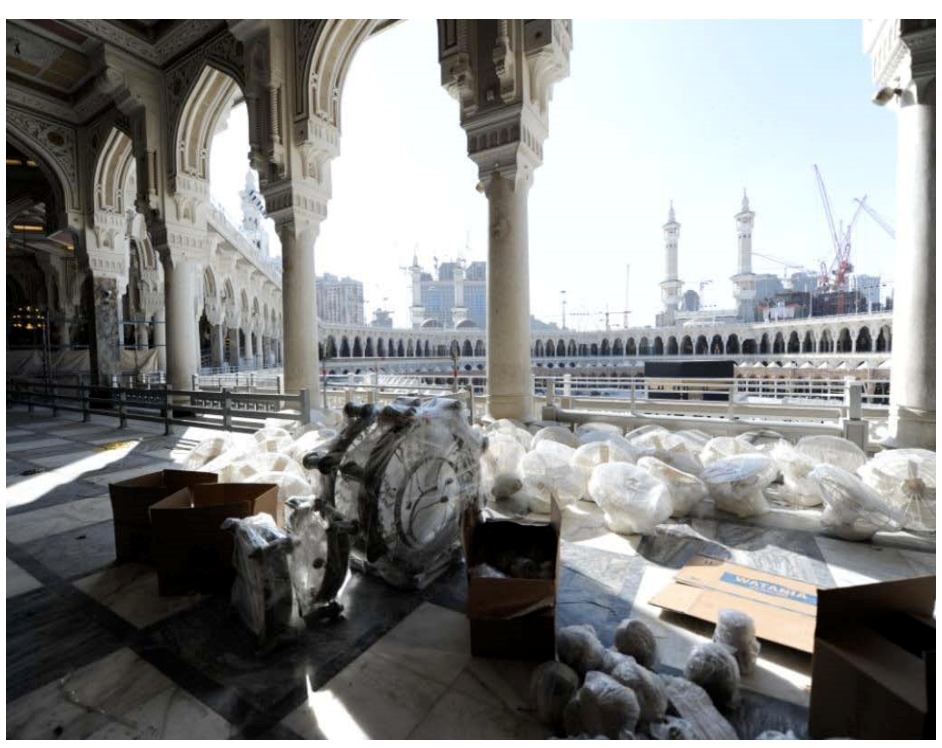

Figure 12. Dismantling and packaging holdings.

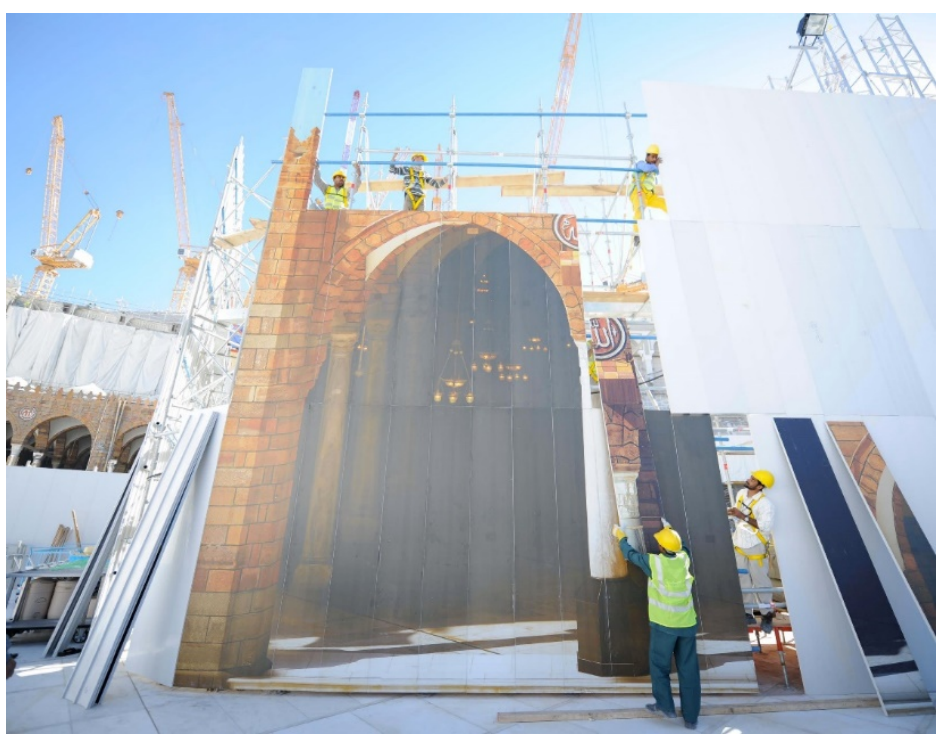

Figure 13. Temporary fences mimic the project shape.

Fifth, cutting the roof slabs for the mockup roof began directly; however, in the project, demolition and cutting the slabs could not start until the marble and roofing system materials were removed from the roof, as shown in Figure 14.

Sixth, the demolition and construction works in the mockups did not require work permits, unlike work on the project. These previously mentioned points made the site conditions and constraints factor the most important one affecting the demolition phase duration and the construction phase duration, and thus the overall project duration. 




Figure 14. Marble and roofing system material removal.

The electrical and mechanical rerouting works factor ranked second in terms of influence on the overall project duration, according to Table 4 , where RII $=0.941$ and Rank $=2$, and it came second in relation to its impact on the demolition phase duration, according to Table 2, where RII $=0.957$ and Rank $=2$. There was a consensus on this factor because all the electrical and mechanical services and systems were operating in integrated systems and continuous loops. For these systems to continue working properly and safely in the rest of the project phases without any disruption, these services had to be transformed and alternative routes found. This ensures that the services work properly and with the required efficiency. In fact, the transfer of electromechanical services is not limited to diverting the routes of these utilities, but also includes rebuilding new service rooms outside the demolition areas and equipping them with all the required equipment and control systems. These rooms are tested and operated temporarily in order to ensure their effectiveness and performance, before handing them over to the authorized entities to obtain permission for removing the old rooms, as shown in Figure 15. Service transfer takes time and delays the demolition work and, as a result, the project as a whole.

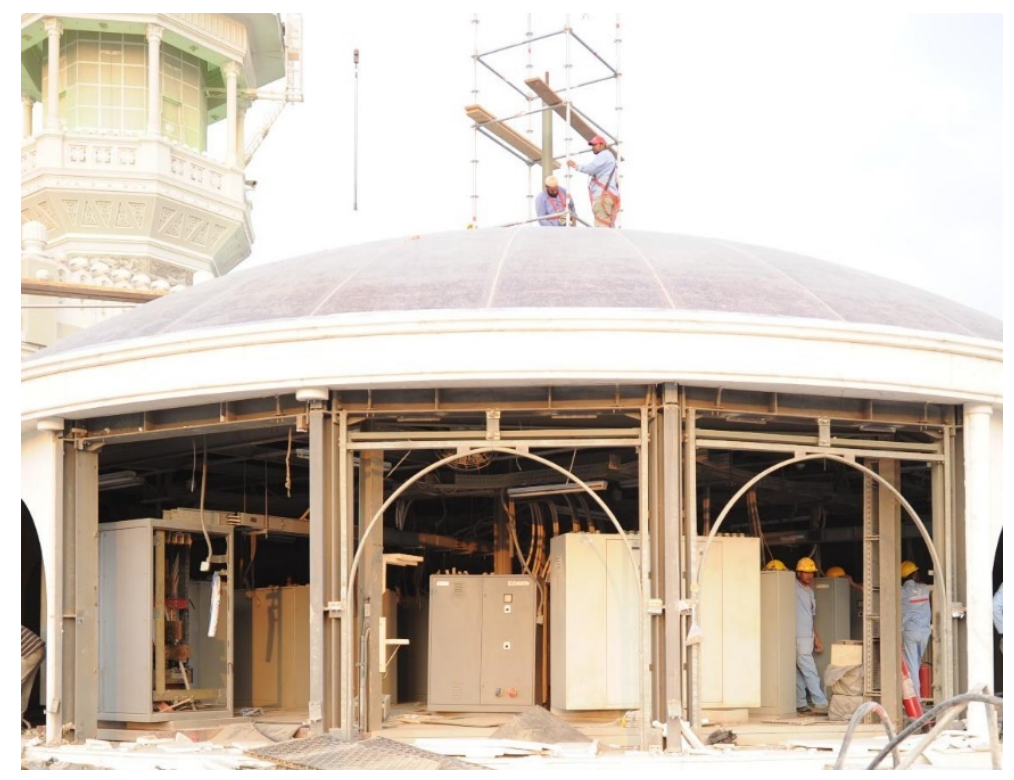

Figure 15. Rerouting work for an electrical service room. 
The design buildability and adjustment factor came third in terms of the impact on the overall project duration, according to Table $4(\mathrm{RII}=0.935$, Rank $=3)$, and second in terms of the impact on the construction phase duration, according to Table 3 (RII $=0.941$, Rank $=2$ ). The most important criterion was large spaces between the columns in order to permit people to move easily among the project zones. Second was the possibility of expanding the project vertically without the need for any demolition work. These were major reasons behind the difficulty of the project design. The steel reinforcement of the raft foundation made it particularly difficult to execute the necessary work as shown in Figure 16. In fact, design difficulties and modifications during the building work delayed the construction phase, and this delay negatively affected the overall project duration.

The creation of safe passageways factor came fourth in terms of its impact on the overall project duration, according to Table $4(\mathrm{RII}=0.871$, Rank $=4)$, and ranked third in terms of impact on the demolition phase duration according to Table $2(\mathrm{RII}=0.917$, Rank $=3$ ) It ranked sixth in terms of the effect on the construction phase duration, according to Table 3 (RII $=0.841$, Rank $=6$ ). In fact, to ensure that visitors move safely between the different project areas, in addition to inside and outside the project, it was necessary to leave passageways within the demolition and construction areas that allowed for easy and safe movement. These safe passageways were an area where work was not permitted. This is evident in Figures 17 and 18, where Figure 17 shows the completion of the demolition work within the first phase area, except for the safe passageway part, which remains suspended until an alternative safe passageway is secured within the construction area, and Figure 18 shows the demolition work in the safe passageway part that has been resumed. In addition, these safe passageways have divided one work area into two completely separate areas, and this imposed additional restrictions on the equipment and the laborers' movement between the work areas, as shown in Figures 17 and 18. The creation of safe passageways within the demolition and construction areas delays the work and, as a result, negatively affects the overall project duration.

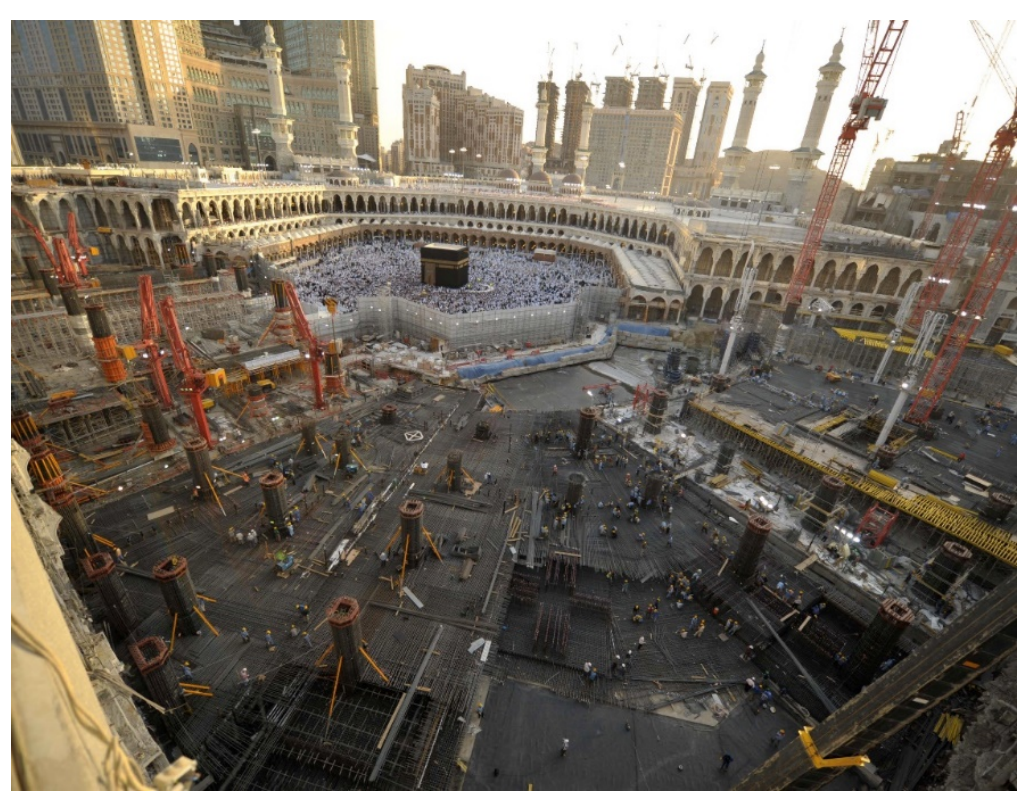

Figure 16. Steel reinforcement density in the raft foundation. 


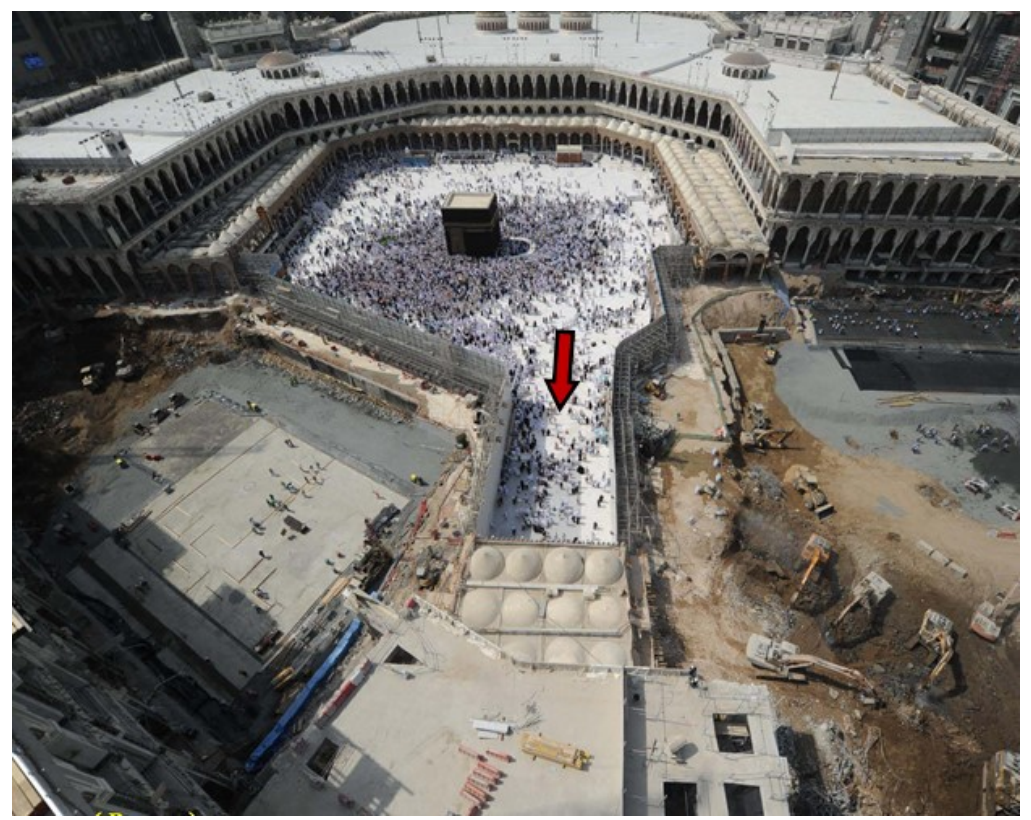

Figure 17. Safe passageway in phase 1 (demolition temporarily on hold), divided the area into parts, and the arrow shows the visitors' movement.

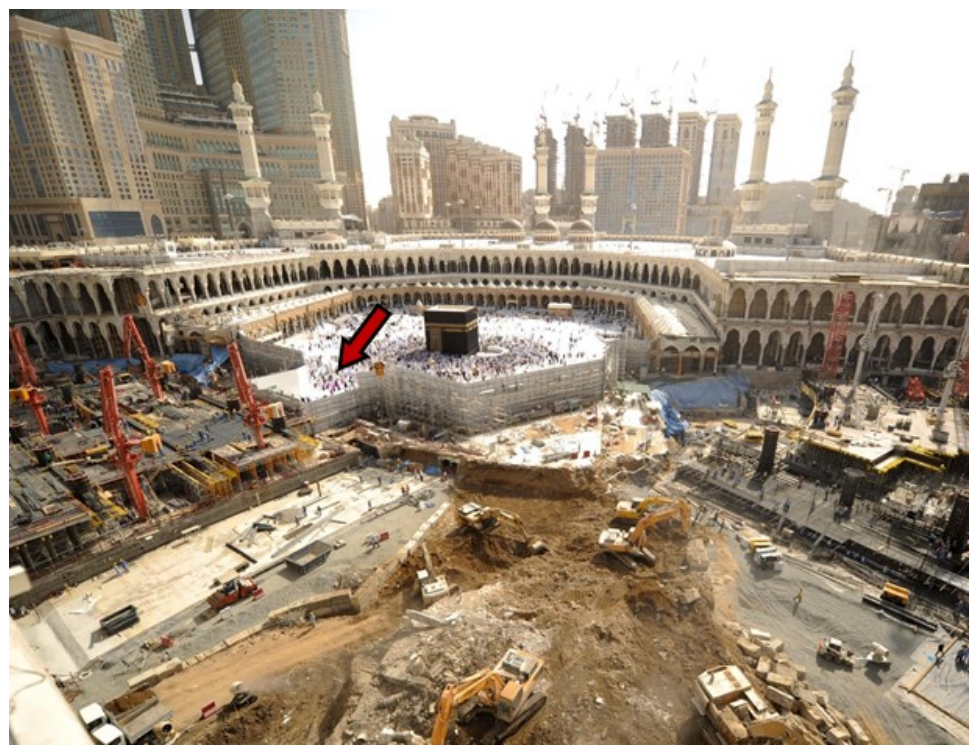

Figure 18. New safe passageway in the construction area, where the arrow shows the visitors' movement.

The historical element dismantling factor came in fifth place in terms of the impact on the overall project duration, according to Table $4(\mathrm{RII}=0.863$, Rank $=5)$, and was ranked fourth in terms of impact on the demolition phase duration, according to Table $2(\mathrm{RII}=0.876$, Rank $=4)$. The negative impact of this factor on the project duration resulted from two main matters. The first is related to the historical building itself, while the second is due to the relationship between the historical and nonhistorical buildings in terms of the overlap between them. In fact, the first negative impact related to the historical building is the result of the procedures that must be taken into account before starting to remove any historical element. These procedures can be summarized first with documentation work that includes surveying, photography, and as-built drawings that accurately show the location of each historical element within the building. Second, manual numbering is completed for all elements on the project site by specialists. Third, protection, propping, and packaging work must be done before dismantling the historical elements and transferring them to special workshops, as shown in 
Figure 19. These procedures are important to preserve the historical elements in order to use them again during the reconstruction phase, but they take time, which negatively affects the project duration. All demolition work in the nonhistorical section adjacent to the historical one had to be stopped until the removal of all the historical elements in overlapping areas was complete, in order to ensure the safety of the historical elements, as shown in Figure 20. This delay negatively affected the overall project duration.

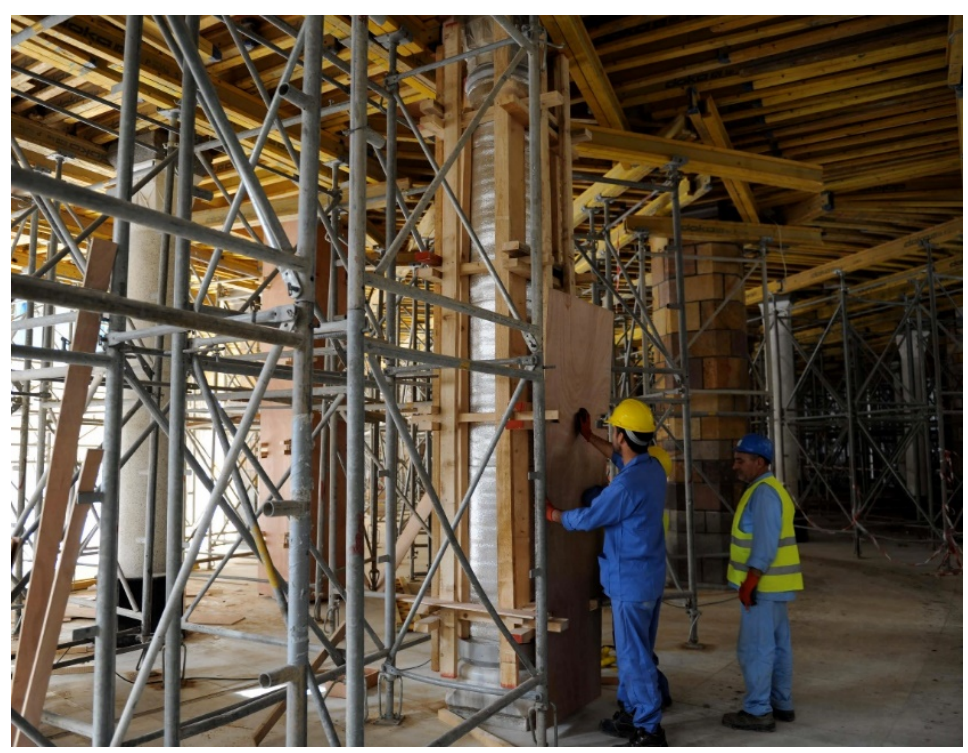

Figure 19. Protection, propping, and packaging of a historical column before dismantling.

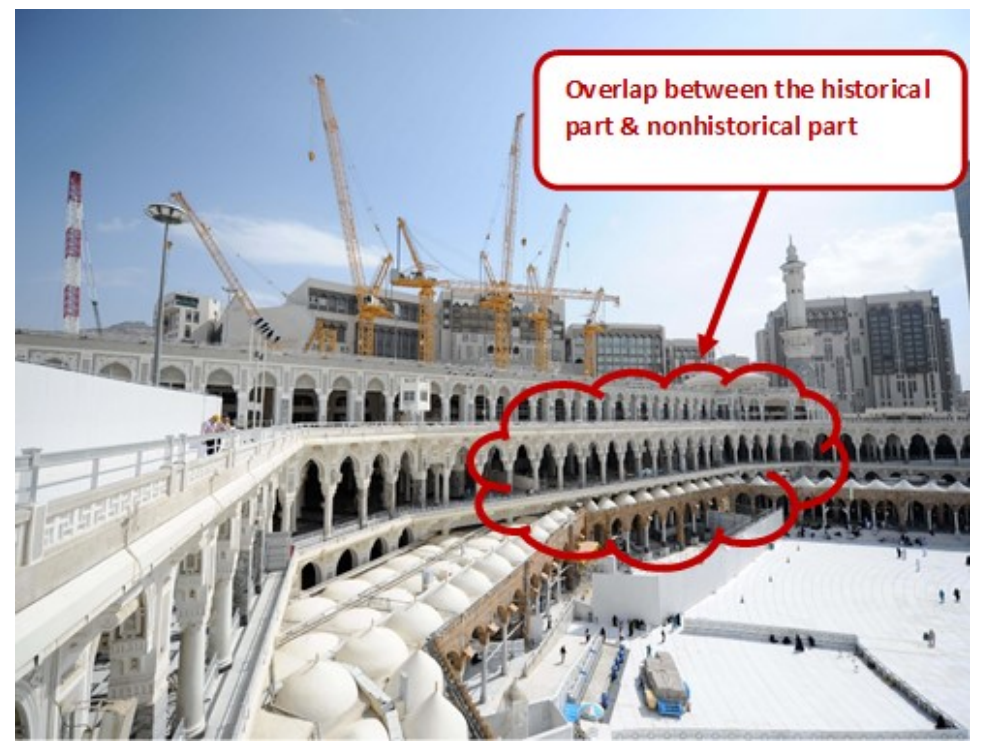

Figure 20. Overlap between the historical part and nonhistorical part.

The overlap between temporary projects and construction works factor came in sixth place in terms of the impact on the overall project duration, according to Table 4 (RII $=0.855$, Rank $=6$ ), while it came fourth in terms of its influence on the construction phase duration, according to Table 3 $(\mathrm{RII}=0.871$, Rank $=4)$. The project was divided into three main phases so that the site did not have to be closed off entirely. With the start of work in the first phase, the space available to visitors decreased, which required the execution of some temporary projects in order to reduce crowding and ensure safe movement. An example is the temporary Mataf project shown in Figure 21. Despite the positive role that this project played in serving visitors and facilitating their safe movement, some of the columns 
and passageways were located within the construction area, which led to work delays. This negatively affects the construction work duration, as reflected in the overall project delay.

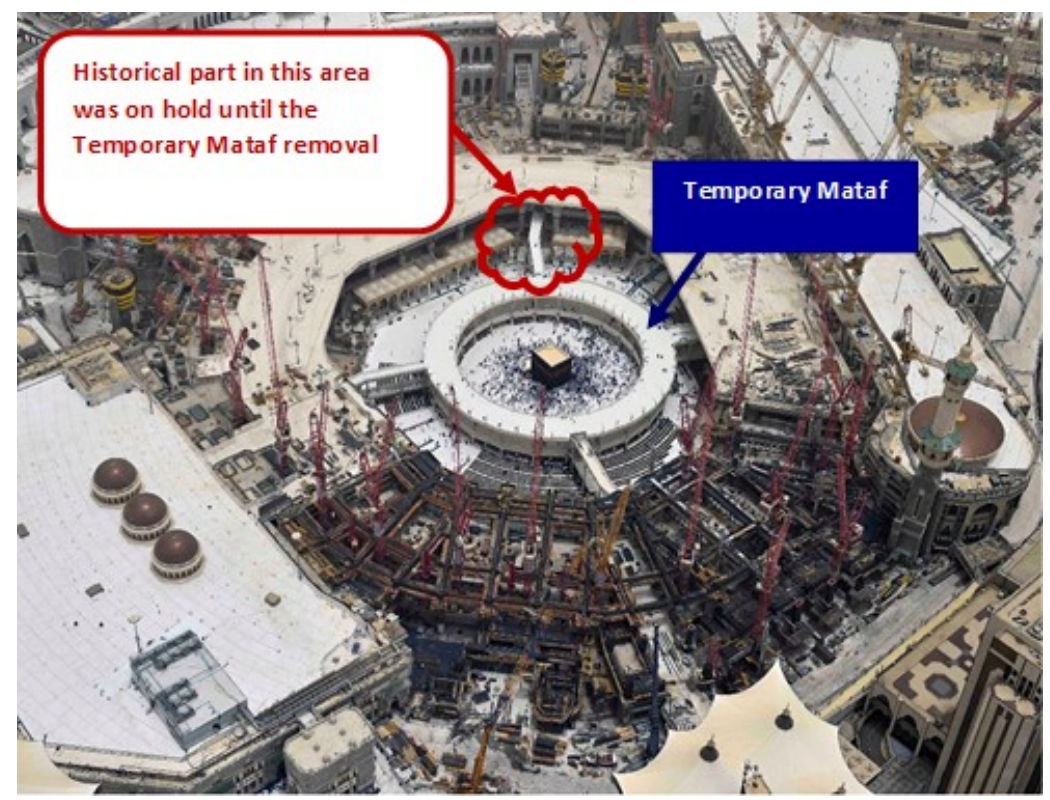

Figure 21. Temporary Mataf project.

The historical elements test period factor came in seventh place in terms of its impact on the overall project duration, according to Table $4(\mathrm{RII}=0.847$, Rank $=7$ ), while it came third in terms of its influence on the construction phase duration, according to Table $3(\mathrm{RII}=0.911$, Rank $=3)$. After unpacking the historical elements, they were transferred to special workshops where they were sorted into various groups according to the type of element. After that, a team of experts conducted a set of tests on these elements in order to assess their historical value, structural status, and durability. Based on the results, the elements of great historical value and high structural capacity were chosen to be used during the reconstruction of the historical building, to secure the building's sustainability while preserving its historical form (Figure 22). This delayed the historical building reconstruction, and negatively impacted the overall project duration.

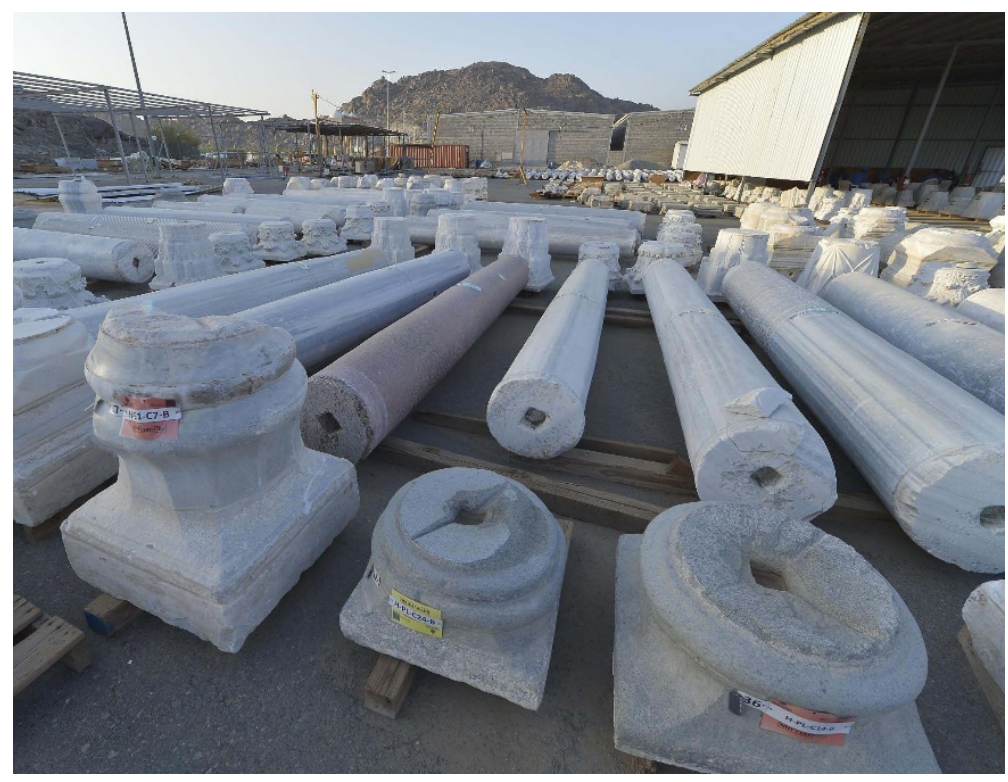

Figure 22. Testing and sorting of some historical elements. 
Workforce productivity rate factor came in eighth place in terms of its impact on the overall project duration, according to Table 4 (RII $=0.833$, Rank $=8$ ), while it came fifth in terms of its impact on the construction phase duration, according to Table 3 (RII $=0.855$, Rank $=5$ ). The laborers' productivity rate decreased due to the difficulty of transporting materials and equipment maneuvering at the site. In addition, the design difficulty, hot weather, and stopping work during prayer times caused delay, which negatively affected the overall project duration.

The overlap between the historical and nonhistorical parts factor came in ninth place in terms of its impact on the overall project duration, according to Table 4 (RII $=0.747$, Rank $=9)$, while it ranked eighth in terms of its effect on the construction phase duration, according to Table 3 (RII $=0.753$, Rank = 8). According to the Health, Safety, and Environmental (HSE) requirements of the project, construction work stopped on the historical parts overlapping with the nonhistorical ones until the end of the construction of the nonhistorical parts. This matter delayed the construction work in the historical building and this delay reflected negatively on the overall project duration.

The alternative materials for the historical elements factor came in tenth place in terms of its impact on the overall project duration, according to Table 4 (RII $=0.745$, Rank $=10)$, while it came seventh in terms of influencing the construction phase duration, according to Table 3 (RII $=0.766$, Rank $=7$ ). One of the most important factors that delayed the construction work in the historical part was the need to get new materials similar to the historical elements and obtain approval from the supervising authorities. In fact, these materials were divided into two main types: materials used in the historical elements' restoration, and materials similar to the historical materials that were used to reconstruct the historical part. Final approval of these materials was not limited to the project specifications, but also subject to the building of multiple models for selecting the most appropriate one that simulates the project's historical form and ensures that the project is structurally and architecturally sustainable (Figure 23). The work to choose the appropriate new materials delayed the start of construction work, which negatively impacted the overall project duration.



Figure 23. Columns, bases, and material mockups for the historical part.

The supporting works factor came in eleventh place in terms of its impact on the overall time project duration, which is the penultimate stage, according to Table 4 (RII $=0.699$, Rank $=11$ ), while it came in fifth place in terms of its impact on the demolition phase duration, which is the last stage, according to Table $2(\mathrm{RII}=0.707$, Rank $=5$ ). Before starting demolition work in any area of the project, necessary supporting work had to be completed based on the approved demolition plan. In fact, the project required additional propping-up, due to the fact that construction was in operation and visitors' safe access had to be ensured, in addition to the large floor height (Figure 24). The propping-up 
required additional time, which affected the demolition phase duration. As a result, it affected the overall project duration.

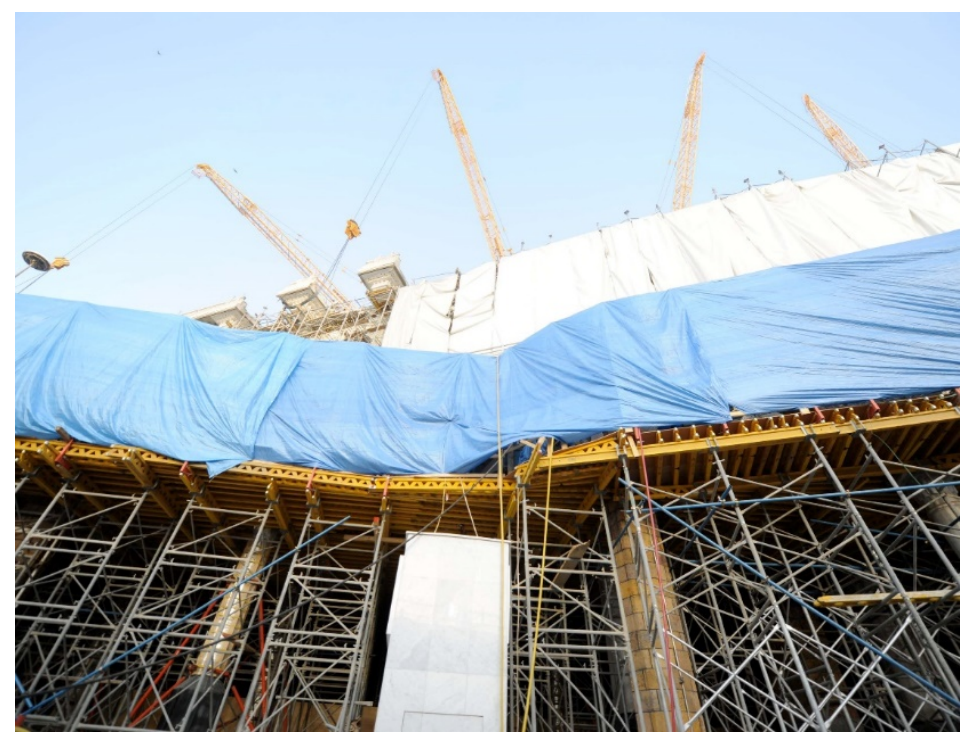

Figure 24. Supporting works.

Delays in the building works next to the demolition area factor came in twelfth in terms of the impact on the overall project duration, according to Table 4 (RII $=0.640$, Rank $=12)$, while it ranked ninth in terms of the impact on the construction phase duration, which is also the last stage, according to Table 3 (RII $=0.648$, Rank =9). In fact, according to the Health, Safety, and Environmental (HSE) requirements, an interval zone between the demolition and construction work had to be left to avoid any possible accidents. Construction work in this zone was not permitted until the demolition work was totally completed in the vicinity. This delayed the start of construction work in the areas adjacent to the demolition zones, which negatively affected the construction work duration and thus the overall project duration.

\section{Conclusions and Recommendations}

Several studies have highlighted and discussed construction projects' delay factors. These studies are still limited to reconstruction projects that are classified into two main phases, namely, a demolition phase and a construction phase.

This study aimed to conduct a comprehensive analysis of reconstruction projects' delay factors, in view of the importance of this type of project, which has recently become widespread. Some buildings need to expand and develop their electromechanical systems in order to match the needs of the times. Reconstruction also takes place in old buildings that are unsafe but of a historical and cultural heritage. Furthermore, reconstruction takes place in buildings that have been affected by natural disasters such as earthquakes or were damaged by conflicts.

This study is a continuation of the previous study conducted by the same researchers on the Mataf Expansion project in Mecca, Saudi Arabia, one of the most important reconstruction projects in the Middle East. This study is based on the delay factors list that resulted from the previous study. It is divided into two parts. The first considers the five factors that negatively affected the demolition phase duration. The second includes nine factors that negatively affected the construction phase duration. It is worth mentioning that, among the previous factors, there are two factors in common between these two parts. In order to achieve the study's goals, a questionnaire was prepared, divided into three parts. The first relates to the five factors affecting the demolition duration. The second relates to the nine factors affecting the construction duration. The last one relates to the factors of the two 
parts combined. There are 12 factors in total after deleting the repeated ones. This was done in order to study the impact on the overall project duration. Ninety-three questionnaires were distributed by hand to experts working on the project. Afterwards, the questionnaire results were analyzed and the delay factors were sorted in descending order according to the relative importance index (RII), as the classification rank shows in Tables 1-3. Table 1 shows the delay factors that negatively affected the demolition phase duration: (1) site restrictions and conditions; (2) electrical and mechanical rerouting works; (3) the creation of safe passageways; (4) historical element dismantling; and (5) supporting works. Table 2 shows the delay factors that negatively affected the construction phase duration: (1) site restrictions and conditions; (2) design buildability and adjustment; (3) historical elements test period; (4) overlap between temporary projects and construction works; (5) workforce productivity rate; (6) the creation of safe passageways; (7) alternative materials for the historical elements; (8) overlap between the historical and nonhistorical parts; (9) delays in the building works next to the demolition area. Due to the overlap between the demolition phase and the construction phase, in addition to the existence of some common factors between these two phases, the final list of delay factors that negatively affected the overall project reconstruction duration (Table 3) is: (1) site restrictions and conditions; (2) electrical and mechanical rerouting works; (3) design buildability and adjustment; (4) the creation of safe passageways; (5) historical element dismantling; (6) overlap between temporary projects and construction works; (7) historical elements test period; (8) workforce productivity rate; (9) overlap between the historical and nonhistorical parts; (10) alternative materials for the historical elements; (11) supporting works; and (12) delays in the building works next to the demolition area.

The study results were discussed with the project and construction managers, who showed a great desire to be informed about the study results. All the comments and clarifications mentioned in response to these results were recorded in detail and clarified in the discussion section.

The research results shed light on the delay factors in the reconstruction projects, and this was clear by classifying these factors according to their negative impact on the project's planned duration. It is worth noting that there are a set of procedures taken by the parties involved in the project. They formed the basis for managing the delay factors and mitigating its negative impacts as possible and avoiding its repetition in later project phases. These procedures are as follows:

- Preparing daily reports which describe the accomplished work in the morning and evening shifts in detail.

- Comparing the performed work on the site daily with the planned one and determining the variance and execution problems.

- Updating the construction schedule and determining the variance according to the baseline schedule.

- Periodical accurate delay analysis and determining the delay period caused by each factor.

- Work plans modification and increasing the equipment and workforce according to the updated plans.

- Emphasizing the coordination between the various managements and the project sections.

- Accelerating the design completion and preparing the shop and coordination drawings.

- Using modern technology and equipment in the project, which allows the acceleration of work.

We strongly advise studying the site location and conditions for the reconstruction projects and implementing an accurate and detailed system for planning, monitoring, and contorting before starting the work on site. We also recommend more research on various kinds of reconstruction projects, whether they are in operation during the reconstruction period or not, to identify all the delay factors that might negatively affect the project duration. As a result, these factors would form a database for experts to better plan a project before starting work on site. In fact, the relative importance index (RII) analysis method, which was employed in this study, showed a strong potential to provide an accurate ranking procedure. In addition, it can facilitate this type of study and form a platform for sorting delay factors according to their effect on reconstruction project planning and duration. 
Author Contributions: Conceptualization, A.E.-S.; data curation, B.A.K.; formal analysis, B.A.K.; fnvestigation, Y.S.P. and A.E.-S.; methodology, B.A.K. and Y.S.P.; supervision, Y.S.P. and A.E.-S.; sriting-original draft, B.A.K.; writing-review and editing, Y.S.P. and A.E.-S. All authors have read and agreed to the published version of the manuscript.

Funding: The authors would like to thank the technical and financial support received from research grant coded UMRG RP025A-18SUS funded by the University of Malaya.

Acknowledgments: The authors would like to thank the data supplier, all reviewers, and the Editor-in-Chief for their insightful comments that have improved the quality of the final manuscript.

Conflicts of Interest: The authors declare no conflict of interest.

\section{References}

1. Chan, A.P.C. Time-cost relationship of public sector projects in Malaysia. Int. J. Proj. Manag. 2001, 19, 223-229. [CrossRef]

2. Assaf, S.A.; Al-Hejji, S. Causes of delay in large construction projects. Int. J. Proj. Manag. 2006, 24, 349-357. [CrossRef]

3. Opeyemi, M.K.; Samson, O.A.; Olabode, O.M.; Olanrewaju, D. An Assessment of the Causative Factors and Effects of Delays in Building Construction Projects in Osun State, Nigeria. J. Econ. Sustain. Dev. 2015, 6, $29-38$.

4. Khatib, B.A.; Poh, Y.S.; El-Shafie, A. Delay Factors in Reconstruction Projects: A Case Study of Mataf Expansion Project. Sustainability 2018, 10, 4772. [CrossRef]

5. Al-Emad, N.; Rahman, I.; Nagapan, S.; Gamil, Y. Ranking of Delay Factors for Makkah's Construction Industry. MATEC Web Conf. 2017, 103, 03001. [CrossRef]

6. Jarkas, A.M.; Haupt, T.C. Major construction risk factors considered by general contractors in Qatar. J. Eng. Des. Tech. 2015, 13, 165-194. [CrossRef]

7. Khoshgoftar, M.; Bakar, A.A.; Osman, O. Causes of delays in Iranian construction projects. Int. J. Proj. Manag. 2010, 10, 53-69. [CrossRef]

8. Memon, H.; Rahman, A.; Akram, M.; Ali, M. Significant factors causing time overrun in construction projects of Peninsular Malaysia. Mod. Appl. Sci. 2014, 8, 16-28. [CrossRef]

9. Sweis, G. Factors Affecting Time Overruns in Public Construction Projects: The Case of Jordan. Int. J. Bus. Manag. 2013, 23, 120-129. [CrossRef]

10. Gündüz, M.; Nielsen, Y.; Özdemir, M. Quantification of Delay Factors Using the Relative Importance Index Method for Construction Projects in Turkey. J. Manag. Eng. 2013, 29, 133-139. [CrossRef]

11. Aziz, R.F. Ranking of delay factors in construction projects after Egyptian revolution. Alex. Eng. J. 2013, 52, 387-406.

12. Gidado, K.; Niazai, G. Causes of project delay in the construction industry in Afghanistan. In Proceedings of the EPPM2012, Brighton, UK, 10-11 September 2012.

13. Mahamid, I. Micro and macro level of dispute causes in residential building projects: Studies of Saudi Arabia. J. King Saud Univ. Eng. Sci. 2014, 1, 12-20. [CrossRef]

14. Al Jurf, N.A.; Beheiry, S. Factors affecting cost and schedule in Qatar's residential compounds projects. Int. J. Eng. Manag. Econ. 2012, 3, 117-134. [CrossRef]

15. Ameh, O.; Osegbo, E. Study of relationship between time overrun and productivity on construction sites. Int. J. Constr. Supply Chain Manag. 2011, 1, 56-67. [CrossRef]

16. Abd El-Razek, M.; Bassioni, H.; Mobarak, A. Causes of Delay in Building Construction Projects in Egypt. J. Constr. Eng. Manag. 2008, 134, 831-841. [CrossRef]

17. Sweis, G.; Sweis, R.; Abu Hammad, A.; Shboul, A. Delays in construction projects: The case of Jordan. Int. J. Proj. Manag. 2008, 26, 665-674. [CrossRef]

18. Toor, S.-U.-R.; Ogunlana, S. Problems causing delays in major construction projects in Thailand. Constr. Manag. Econ. 2008, 26, 395-408. [CrossRef]

19. Faridi, A.; Sayegh, S. Significant factors causing delay in the UAE construction industry. Constr. Manag. Econ. 2006, 24, 1167-1176. [CrossRef] 
20. Chan, D.; Kumaraswamy, M. A comparative study of causes of time overruns in Hong Kong construction projects. Int. J. Proj. Manag. 1997, 15, 55-63. [CrossRef]

21. Mansfield, N.R.; Ugwu, O.O.; Doran, T. Causes of delay and cost overruns in Nigerian construction projects. Int. J. Proj. Manag. 1994, 12, 254-260. [CrossRef]

22. Al-Kharashi, A.; Skitmore, M. Causes of delays in Saudi Arabian public sector construction projects. Constr. Manag. Econ. 2009, 27, 3-23. [CrossRef]

23. Alinaitwe, H.; Apolot, R.; Tindiwensi, D. An Investigation into the Causes of Delay and Cost Overrun in Uganda's Public Sector Construction Projects. J. Constr. Dev. Ctries. 2013, 18, 33.

24. Doloi, H.; Sawhney, A.; Iyer, K.; Rentala, S. Analysing factors affecting delays in Indian construction projects. Int. J. Proj. Manag. 2012, 30, 479-489. [CrossRef]

25. Sambasivan, M.; Soon, Y. Causes and effects of delays in Malaysian construction industry. Int. J. Proj. Manag. 2007, 25, 517-526. [CrossRef]

26. Al-Khalil, M.; Al-Ghafly, M. Delay in public utility projects in Saudi Arabia. Int. J. Proj. Manag. 1999, 17, 101-106. [CrossRef]

27. Arditi, D.; Gutierrez, A.E. Factors affecting U.S. contractors' performance overseas. J. Constr. Eng. Manag. 1991, 117, 27-46. [CrossRef]

28. Enshassi, A.; Mohamed, S.; Abushaban, S. Factors affecting the performance of construction projects in the Gaza strip. J. Civ. Eng. Manag. 2009, 15, 269-280. [CrossRef]

29. Alaghbari, W.; Razali, M.; Kadir, S.; Ernawat, G. The significant factors causing delay of building construction projects in Malaysia. Eng. Constr. Arch. Manag. 2007, 14, 192-206. [CrossRef]

30. Lo, T.Y.; Fung, I.W.H.; Tung, K.C.F. Construction delays in Hong Kong civil engineering projects. J. Constr. Eng. Manag. ASCE 2006, 132, 636-649. [CrossRef]

31. Mezher, T.; Tawil, W. Causes of delays in the construction industry in Lebanon. Eng. Constr. Arch. Manag. J. 1998, 5, 252-260. [CrossRef]

32. Assaf, S.A.; Al-Khalil, M.; Al-Hazmi, M. Causes of delay in large building construction projects. ASCE J. Manag. Eng. 1995, 11, 45-50. [CrossRef]

33. Gardezi, S.S.; Manarvi, I.A.; Gardezi, S.J. Time Extension Factors in Construction Industry of Pakistan. Procedia Eng. 2014, 77, 196-204. [CrossRef]

34. Mahamid, I. Contributors to schedule delays in public construction projects in Saudi Arabia: Owners' perspective. J. Constr. Proj. Manag. Innov. 2013, 3, 608-619.

35. Fallahnejad, M. Delay causes in Iran gas pipeline projects. Int. J. Proj. Manag. 2012, 31, 136-146. [CrossRef]

36. Mahamid, I. Common risks affecting time overrun in road construction projects in Palestine: Contractors' perspective. Constr. Econ. Build. 2013, 13, 45-53. [CrossRef]

37. Le-Hoai, L.; Lee, Y.; Lee, J. Delay and Cost Overruns in Vietnam Large Construction Projects: A Comparison with Other Selected Countries. KSCE J. Civ. Eng. 2008, 12, 367-377. [CrossRef]

38. Kazaz, A.; Ulubeyli, S.; Tuncbilekli, N. Causes of Delays in Construction Projects in Turkey. J. Civ. Eng. Manag. 2012, 18, 426-435. [CrossRef]

39. Ogunlana, S.O.; Promkuntong, K.; Jearkjirm, V. Construction delays in a fast-growing economy: Comparing Thailand with other economics. Int. J. Proj. Manag. 1996, 14, 37-45. [CrossRef]

40. Kaming, P.; Olomolaiye, P.; Holt, G.; Harris, F. Factors influencing construction time and cost overruns on high-rise projects in Indonesia. Constr. Manag. Econ. 1997, 15, 83-94. [CrossRef]

41. Dlakwa, M.M.; Culpin, M.F. Reasons for overrun in public sector construction projects in Nigeria. Int. J. Proj. Manag. 1990, 8, 237-241. [CrossRef]

42. Aibinu, A.A.; Odeyinka, A. Construction delays and their causative factors in Nigeria. J. Constr. Eng. Manag. ASCE 2006, 132, 667-677. [CrossRef]

43. Mydin, M.; Sani, N.; Salim, N.; Alias, N. Assessment of Influential Causes of Construction Project Delay in Malaysian Private Housing from Developer's Viewpoint. E3S Web Conf. 2014, 3, 01027. [CrossRef]

44. Arditi, D.; Akan, G.T.; Gurdamar, S. Reasons for delays in public projects in Turkey. Constr. Manag. Econ. 1985, 3, 171-181. [CrossRef]

45. Abdul-Rahman, H.; Berawi, M.A.; Berawi, A.R.; Mohamed, O.; Othman, M.; Yahya, I.A. Delay mitigation in the Malaysian construction industry. J. Constr. Eng. Manag. 2006, 132, 125-133. [CrossRef] 
46. Frimpong, Y.; Oluwoye, J.; Crawford, L. Causes of delay and cost overruns in construction of groundwater projects in a developing countries; Ghana as a case study. Int. J. Proj. Manag. 2003, 21, 321-326. [CrossRef]

47. Acharya, N.K.; Lee, Y.D.; Im, H.M. Investigating delay factors in construction industry: A Korean perspective. Korean J. Constr. Eng. Manag. 2006, 10, 177-190.

(c) (

(C) 2020 by the authors. Licensee MDPI, Basel, Switzerland. This article is an open access article distributed under the terms and conditions of the Creative Commons Attribution (CC BY) license (http://creativecommons.org/licenses/by/4.0/). 